\section{Abnormal insulin secretion in children with coeliac disease}

Sir,

The paper by Dr. Day and her colleagues (Day, Evans, and Wharton, Archives, 1973, p. 41) describing reduced insulin and growth hormone responses to tolbutamide in children with coeliac disease prompted me to re-examine insulin values obtained during diagnostic oral glucose tolerance tests in young children admitted to The Hospital for Sick Children, Great Ormond Street, with a variety of disorders.

Results were available in 8 children aged 1.3 to 6.0 years with coeliac disease. In 5 children the diagnosis was confirmed by biopsy and the clinical response to a gluten-free diet left little doubt as to the accuracy of the diagnosis in the remaining patients. The weights of 4 children were below the third centile. All were receiving a normal diet at the time of investigation. Another 6 children, ages 0.4 to 2.7 years, had a history of diarrhoea for which no cause could be found. The weights of all these children were above the third centile. In a further 7 children, aged 0.6 to 4.9 years, hypoglycaemia was suspected but not confirmed. The weights of all but one of these children lay above the third centile and 5 were mentally retarded. The insulin results in these last 2 groups have been published elsewhere (Grant, 1968), together with details of the methods used.

Only minor changes in serum insulin were found in the children with coeliac disease, and none had a level above $15 \mu \mathrm{U} / \mathrm{ml}$ after glucose. The mean insulin values 30 and 60 minutes after glucose were significantly lower than those obtained in children with unexplained diarrhoea or suspected hypoglycaemia (Table). All but one of the children with coeliac disease showed a rise in blood sugar after glucose. The mean blood sugar values for the coeliac group were lower than the corresponding levels for the other groups but, with one exception (Table), the differences were not significant.

The findings in this small group of patients support the thesis that serum insulin levels are reduced in children with coeliac disease. At the time the results were obtained it seemed that insulin estimation might add to the value of the oral glucose tolerance test as a screening test for coeliac disease. The success of the peroral biopsy technique has made such a test largely unnecessary, but the results still serve to emphasize the advice of Day et al. that coeliac disease should be considered if low serum insulin levels are obtained during stimulation tests.

D. B. GRANT Clinical Research Centre, Watford Road, Harrow, Middlesex HA1 3UJ.

\section{REFERENCES}

Day, G., Evans, K., and Wharton, B. (1973). Abnormalities of insulin and growth hormone secretion in children with coeliac disease. Archives of Disease in Childhood, 48, 41.

Grant, D. B. (1968). Serum-insulin levels in children during glucose tolerance tests. Acta Paediatrica Scandinavica, 57, 297.

\title{
TABLE
}

Mean serum insulin values $( \pm S E M)$ in children with coeliac disease, unexplained diarrhoea, and suspected but unconfirmed hypoglycaemia

\begin{tabular}{|c|c|c|c|c|c|c|c|}
\hline \multirow{2}{*}{ Diagnosis } & \multirow{2}{*}{ No. } & \multicolumn{6}{|c|}{ Time (min) } \\
\hline & & -5 & +30 & +60 & +90 & +120 & +150 \\
\hline $\begin{array}{l}\text { Coeliac disease } \\
\text { Unexplained diarrhoea } \\
\text { Suspected but unconfirmed } \\
\text { hypoglycaemia }\end{array}$ & 8 & $\begin{aligned} 1 & \pm 0 \cdot 4 \\
(80 & \pm 3) \\
2 & \pm 0 \cdot 5 \\
(77 & \pm 5) \\
4 & \pm 2 \cdot 0 \\
(78 & \pm 4)\end{aligned}$ & $\begin{array}{c}7 \pm 1 \cdot 7 \\
(97 \pm 6) \\
25 \pm 4 \cdot 7^{\star} \\
(136 \pm 13) \dagger \\
28 \pm 7 \cdot 3 \dagger \\
(108 \pm 7)\end{array}$ & $\begin{aligned} & 7 \pm 1 \cdot 2 \\
&(101 \pm 6) \\
& 17 \pm 3 \cdot 1^{\star} \\
&(113 \pm 9) \\
& 22 \pm 3 \cdot 7^{\star} \\
&(108 \pm 7)\end{aligned}$ & $\begin{array}{c}5 \pm 0 \cdot 7 \\
(92 \pm 4) \\
14 \pm 5 \cdot 8 \\
(100 \pm 15) \\
17 \pm 4 \cdot 2 \dagger \\
(98 \pm 5)\end{array}$ & $\begin{array}{c}2 \pm 0 \cdot 9 \\
(85 \pm 8) \\
6 \pm 2 \cdot 5 \\
94 \pm 9 \\
19 \pm 4 \cdot 4^{\star} \\
(94 \pm 9)\end{array}$ & $\begin{aligned} 4 & \pm 1 \cdot 5 \\
(83 & \pm 6) \\
7 & \pm 3 \cdot 2 \\
(79 & \pm 5) \\
10 & \pm 2 \cdot 8 \\
(88 & \pm 8)\end{aligned}$ \\
\hline
\end{tabular}

Note: Mean values for blood sugar are given in parentheses. Values significantly higher than the corresponding levels in the coeliac group are indicated $\star \mathrm{P}<0.01,+\mathrm{P}<0.05$ (Student's ' $\mathrm{t}$ ' test). 